\title{
Modelling and valuing the environmental impacts of arable, forestry and agroforestry systems: a case study
}

Silvestre Garcia de Jalon ${ }^{1}{ }^{*}$, Anil Graves ${ }^{1}$, Joao HN Palma ${ }^{2}$, Adrian Williams ${ }^{1}$, Matt Upson ${ }^{1}$, Paul J. Burgess $^{1}$

(1) Cranfield University. Cranfield, Bedfordshire, MK43 OAL, United Kingdom

(2) Forest Research Centre, School of Agriculture, University of Lisbon, Lisbon, Portugal

\begin{abstract}
The use of land for intensive arable production in Europe is associated with a range of externalities that typically impose costs on third parties. The introduction of trees in arable systems can potentially be used to reduce these costs. This paper assesses the profitability and environmental externalities of a silvoarable agroforestry system, and compares this with the profitability and environmental externalities from an arable system and a forestry system. A silvoarable experimental plot of poplar trees planted in 1992 in Bedfordshire, Eastern England, was used as a case study. The Yield-SAFE model was used to simulate the growth and yields of the silvoarable, arable, and forestry land uses along with the associated environmental externalities, including carbon sequestration, greenhouse gas emissions, nitrogen and phosphorus surplus, and soil erosion losses by water. The Farm-SAFE model was then used to quantify the monetary value of these effects. The study assesses both the financial profitability from a farmer perspective and the economic benefit from a societal perspective. The arable option was the most financially profitable system followed by the silvoarable system and forestry. However, when the environmental externalities were included, silvoarable agroforestry provided the greatest benefit. This suggests that the appropriate integration of trees in arable land can provide greater well-being benefits to society overall, than arable farming without trees, or forestry systems on their own.
\end{abstract}

Keywords: Yield-SAFE, Farm-SAFE, silvoarable, externality, profitability, valuation

Published by Springer. This is the Author Accepted Manuscript issued with: Creative Commons Attribution Non-Commercial License (CC:BY:NC 4.0).

The final published version (version of record) is available online at DOI:10.1007/s10457-017-0128-z.

Please refer to any applicable publisher terms of use. 


\section{Introduction}

The objectives of the EU Common Agricultural Policy are to ensure: i) viable food production, ii) balanced territorial development, and iii) sustainable management of natural resources, with a focus on greenhouse gas emissions, biodiversity, soil and water (Article 110 in EU 2013). Silvoarable agroforestry (the integration of trees and/or shrubs with arable production) is a land use that could help achieve these objectives.

Over recent decades, many agricultural systems in Europe have been simplified through intensification and mechanisation in order to reduce management cost and labour (Dupraz et al. 2005; Burgess and Morris 2009), whilst at the same time becoming increasingly reliant on external inputs such as fuel, nutrients, pesticides, and machinery (Palma et al. 2007). These systems have enabled the competitive production of high quantities of safe and low cost food for consumers without the need to expand the area of agricultural land. However, many systems have resulted in significant negative environmental costs that are borne by society as a whole, rather than individual producers or consumers. These costs, or externalities, include water pollution (leaching and runoff of nitrogen, phosphorus and pesticides), soil degradation (e.g. erosion, compaction and loss of soil organic matter and soil biodiversity), and greenhouse gas (GHG) emissions such as $\mathrm{CO}_{2}, \mathrm{CH}_{4}$ and $\mathrm{N}_{2} \mathrm{O}$. These environmental externalities are rarely accounted for in the profitability analysis of agricultural systems, because they usually have no market value.

Past research has found that environmental externalities from arable systems can be reduced by the appropriate integration of trees, which provide a means of mitigating climate change through carbon sequestration (e.g. Nair 2011; Upson and Burgess 2013), reducing soil degradation (e.g. Graves et al. 2015), and reducing adverse impacts on water quality from agrochemical use (e.g. Palma et al. 2007). However, whilst planting trees on arable land can help reduce environmental externalities, the uptake of silvoarable agroforestry remains relatively slow. This could be a result of the cost of tree planting and management reducing immediate profitability, and the uncertainty regarding the long-term financial benefits from harvesting mature trees. In the EU, efforts have been made to promote adoption of silvoarable systems through policy (Rural Development Measure 222 and Rural Development Measure 8.2) and projects such as SAFE (Dupraz et al. 2005) and AGFORWARD (Burgess et al. 2015) have been funded to provide scientific guidance on the costs and benefits of implementing silvoarable systems across Europe.

For long rotation systems such as agroforestry and forestry, modelling becomes essential. In recent years various biophysical models such as Hi-sAFe (Dupraz et al. 2004), SCUAF (Young et al. 1998), WaNuLCAS (van Noordwijk and Lusiana 1999), and Yield-SAFE (Van der Werf et al. 2007) have been developed to simulate the growth and interaction of trees and crops in silvoarable systems. Some economic models have also been developed to assess the financial profitability of silvoarable systems. These for example, include POPMOD (Thomas 1991), ARBUSTRA (Liagre 1997), and FarmSAFE (Graves et al. 2011).

On the SAFE project, the Farm-SAFE model (Graves et al. 2011) was developed to use Yield-SAFE tree and crop growth data for financial analyses of arable, silvoarable and forestry land uses. More recently on the AGFORWARD project, Yield-SAFE has been adapted to quantify selected environmental externalities of arable, silvoarable and forestry land uses, whilst Farm-SAFE has been 
adapted to use these data in order to assess both financial profitability from a farmer perspective and economic profitability from a societal perspective. Using the adapted Farm-SAFE model, this paper evaluates and compares the biophysical development, financial profitability, and social impact of environmental externalities for arable, forestry, and silvoarable poplar systems to provide a more complete assessment of the economic benefits and costs of these land uses.

\section{Methods and data}

The methodological framework of this study is separated into five stages: i) simulation of the biophysical growth of trees and crops for an experimental-plot case study, ii) assessment of financial performance, iii) quantification of the environmental externalities, iv) conversion of the environmental externalities into monetary terms, and $v$ ) assessment of full economic performance through inclusion of the environmental externalities in the analysis.

\subsection{Bedfordshire case study}

The case study is based on an experiment in Silsoe in Bedfordshire, Eastern England comprising 2.5 ha of silvoarable (poplar + cultivated crops) and forestry (poplar + fallow land) treatments surrounded by one hectare of conventionally cropped arable land (Burgess et al. 2005). The site is located in a relatively flat area at $59 \mathrm{~m}$ above mean sea level. The mean soil texture is $55 \%$ clay, $26 \%$ silt, and $19 \%$ sand. Annual rainfall ranges from $410 \mathrm{~mm}$ to $867 \mathrm{~mm}$ and mean annual temperature from $9.1^{\circ} \mathrm{C}$ to $11.3^{\circ} \mathrm{C}$.

Four poplar hybrid varieties, including Beaupré (Populus trichocarpa $\times$ P. deltoides), were planted in 1992. The four hybrids were planted at a spacing of $6.4 \mathrm{~m}$ in a North-South orientation along rows spaced $10 \mathrm{~m}$ apart. This work only modelled the Beaupré poplar hybrid. Tree height and diameter at breast height were measured at intervals until 2011, when the poplars were harvested, 19 years after planting, because the experimental site was sold for housing development.

\subsection{Biophysical simulation}

Because poor management led to crop failure in some years, a standardised crop rotation of winter wheat, winter wheat, spring barley and oilseed rape was assumed for the financial and economic analysis. The crop yields and the tree growth were simulated using the Yield-SAFE biophysical model (van der Werf et al. 2007) calibrated using the tree growth of the Beaupré hybrid and the relative crop yields obtained in the silvoarable system relative to the arable control (Burgess et al. 2005). Daily climatic data were retrieved from CliPick (Palma et al. 2015). In this way, crop and tree growth simulations were derived for three systems: i) a control arable system, ii) a silvoarable system (Beaupré at a density of 156 trees per hectare and arable cropping for 14 years), and iii) a forestry system (Beaupré at a density of 156 trees per hectare). The length of the tree rotation was specified as 30 years.

The modelled mean control crop yields of $9.06 \mathrm{t} \mathrm{ha}^{-1}, 8.51 \mathrm{t} \mathrm{ha} \mathrm{s}^{-1}, 6.70 \mathrm{t} \mathrm{ha}^{-1}$ and $3.49 \mathrm{t} \mathrm{ha}^{-1}$ for winter wheat first year, winter wheat second year, spring barley and oilseed rape respectively are similar to mean yields reported for the UK by Agro Business Consultants (2015) (Figure 1a) which were used 
for the model calibration in the arable system. The simulated crop yields in the silvoarable system (Figure $1 \mathrm{~b}$ ) declined as the tree canopy expanded, with the final crop grown 14 years after tree planting (i.e. three years longer than achieved in practice). In the silvoarable system, $91 \%$ of the area was occupied by the crop component and $9 \%$ of the area by the tree rows.

\subsection{Financial analysis}

The financial performance of arable, forestry and silvoarable system was assessed using Farm-SAFE (Graves et al. 2011) on the basis of the annual net margins per hectare. The net margin was calculated as revenues from harvested products (grain, straw, timber and firewood) and grants minus variable costs (e.g. crop seed, tree planting, fertiliser, crop and tree protection, pruning, thinning, cutting and other costs) and assignable fixed costs (e.g. installation and repairs of infrastructure, fuel and energy, machinery, insurance and labour and rented machinery costs).

Because people generally prefer to receive goods and services in the present rather than the future, revenues and costs were discounted and converted into financial net present values $\left(N P V_{F}: € h a^{-1}\right)$, denoted using Equation 1:

$N P V_{F}=\sum_{t=0}^{n}\left(\frac{\left(R_{t}-V C_{t}-F C_{t}\right)}{(1+i)^{t}}\right)$

where $R_{t}, V C_{t}$, and $F C_{t}$ were respectively revenue, variable costs, and assignable fixed costs in year $t$ $\left(€ \mathrm{ha}^{-1}\right), i$ was the discount rate, and $n$ was the time horizon for the analysis. A discount rate of $4 \%$ was chosen, as this is marginally above the discount rate of $3.5 \%$ used by the UK Government for cost-benefit analysis in ecological restoration projects (HM Treasury 2003).

The financial profits of the different systems were compared in terms of a financial equivalent annual value $\left(E A V_{F}: €\right.$ ha $^{-1}$ year $\left.^{-1}\right)$ using Equation 2:

$E A V_{F}=N P V_{F}\left(\frac{(1+i)^{n}}{(1+i)^{n}-1}\right) i$

Financial data (Table 1) related to the crops were obtained from a 2015 farm management handbook (Agro Business Consultants 2015), e.g. a wheat grain price of $£ 125 \mathrm{t}^{-1}$. The assumed crop prices were then assumed for the full rotation cycle. The grant receipts were based on the Basic Payment Scheme (BPS) for lowlands in England ( $\left.235 € \mathrm{ha}^{-1} \mathrm{yr}^{-1}\right)$ also in 2016.

$<$ INSERT TABLE 1>

Table 2 shows the summary of costs for the tree component in the silvoarable and forestry system. The silvicultural management and the associated costs and labour inputs were derived from the experimental plot in the Bedfordshire case study. The woodland planting grant was considered only for the forestry system which as a wide-spaced broadleaved system was eligible for support (1888.90 $€ \mathrm{ha}^{-1}$ paid upon completion in the first year and $472.20 € \mathrm{ha}^{-1} \mathrm{yr}^{-1}$ during the first five years (Agro Business Consultants 2015)). The price of the timber including transport was $€ 28 \mathrm{t}^{-1}$.

$<$ INSERT TABLE 2> 


\subsection{Modelling the environmental externalities}

\subsubsection{Greenhouse gas (GHG) emissions}

A Life Cycle Assessment (LCA) model (Williams et al. 2010) was integrated into the Farm-SAFE model to derive GHG emissions in carbon dioxide equivalents $\left(\mathrm{CO}_{2} \mathrm{e}\right)$ associated with the manufacture and use of machinery and agrochemicals. The analysis focused only on $\mathrm{CO}_{2}$ emissions and did not consider $\mathrm{N}_{2} \mathrm{O}$. In order to compare the arable, forestry and silvoarable systems, a functional unit of one hectare was used in the analysis. Equation 3 shows the emissions that were included in the LCA:

Emi. $\mathrm{CO}_{2} e_{t}=M_{m}+M_{f}+M_{p}+F$

Eq. 3

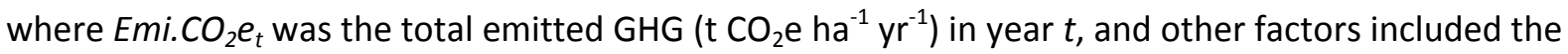
emissions from the manufacture of field machinery $\left(M_{m}\right)$, fertiliser $\left(M_{f}\right)$ and pesticides $\left(M_{p}\right)$ and the emissions associated with the fuel used for field operations $(F)$. For the arable system and silvoarable intercrop area, machinery operations included cultivation, agrochemical application, harvesting and baling. In the forestry system and the tree component of the silvoarable system, the machinery operations included site preparation (ground preparation, full weeding, marking out, planting, tree protection and grass sward establishment), agrochemical application (localised weeding) and harvesting (pruning, epicormics removal, grass sward maintenance and clear felling). Nursery costs were not included. The GHG emissions of the silvoarable system were calculated by adding the GHG emissions of the intercrop area and the tree component area together. Emissions from manufacture of machinery were based on a per hectare utilisation rate calculated from the estimated life expectancy of the machinery (Nix 2014). Emissions from manufacturing field diesel, fertiliser, and pesticides were calculated from the per hectare quantities used. Emissions to the atmosphere from field diesel, fertiliser, and pesticides were also traced back to the quantities used.

A 'cradle-to-field gate' approach was applied i.e. emissions associated with grain drying, crop storage and downstream processing were excluded. The construction of farm infrastructure was also excluded. The GHG emissions from land-use change were not included.

\subsubsection{Aboveground-biomass carbon sequestration}

Estimates for aboveground carbon sequestration were obtained from the simulated tree growth. It was assumed that the carbon sequestered by the arable crops and tree branches would be quickly lost to the atmosphere after harvest and hence they were excluded from the analysis. Equation 4 was used to convert the simulated biomass into carbon dioxide equivalent sequestration $\left(\mathrm{t}_{\mathrm{CO}_{2}} \mathrm{e} \mathrm{ha}{ }^{-1}\right.$ $\left.\mathrm{yr}^{-1}\right)$ :

Seq. $\mathrm{CO}_{2} e_{t}=0.50 \beta_{\text {timber }, t} * \frac{\text { Atomic weight } \mathrm{CO}_{2}}{\text { Atomic weight } C}$ Eq. 4

where Seq. $\mathrm{CO}_{2} e_{t}$ was the sequestered carbon dioxide equivalent $\left({\mathrm{t} \mathrm{CO}_{2} \mathrm{e} \mathrm{ha}}^{-1} \mathrm{yr}^{-1}\right)$ in time $\mathrm{t}$, where 0.50 was assumed to be the carbon content of dry timber (Nair 2011), $b_{\text {timber }}$ was the annual increment in timber mass on a dry weight basis, and the final component converts carbon to a carbon dioxide equivalent. 


\subsubsection{Soil erosion losses by water}

The Revised Universal Soil Loss Equation (RUSLE) was used in Farm-SAFE to calculate the annual soil loss by water (Equation 5 ):

$A_{t}=R K L S C_{t} P$

Eq. 5

where $A_{t}$ was the estimated average soil loss in year $\mathrm{t}\left(\mathrm{t} \mathrm{ha} \mathrm{yr}^{-1} \mathrm{yr}^{-1}\right), R$ is the rainfall-runoff erosivity factor, $K$ is soil erodibility, $L$ is slope length, $S$ is slope steepness, $C$ relates to cover-management, and $P$ relates to support practice that reduces the erosion potential of runoff. The values for $R, K, L$ and $S$, determined by climatic, soil and topographic characteristics, were obtained from the European Soil Data Centre (ESDAC) database for the geographical location of the Bedfordshire case study (see Panagos et al. 2014; Panagos et al. 2015a; Panagos et al. 2015b).

In order to compare soil erosion losses between arable, forestry, and silvoarable systems in the same geographical location, the dynamic change in the cover-management factor $\left(C_{t}\right)$ in year $t$ was calculated for each system drawing on Palma et al. (2007) using Equation 6:

$C_{t}=\operatorname{Cov}_{\text {crop }, t} C_{\text {crop }}+\operatorname{Cov}_{\text {tree }, t} C_{\text {tree }}$

where $\operatorname{Cov}_{\text {crop,t }}$ was the proportion of cropped land in year $t, C_{\text {crop }}$ was the cover-management factor of the crop component, $\operatorname{Cov}_{\text {tree, } t}$ was the proportion of land under the tree component in year $t$, and $C_{\text {tree }}$ was the cover-management factor of the tree component. A common value for the $P$ factor, among the three land uses, was obtained from the ESDAC database (Panagos et al. 2015c).

This approach was a development of the approach reported by Palma et al. (2007). In Palma et al. (2007), the land cover proportion of the crop and tree component were static (time-invariant), whereas our approach considered the change in land cover proportions, and hence the decrease in cover-management factor, as the tree grows.

\subsubsection{Nitrogen surplus}

The nitrogen surplus $\left(N_{\text {sur; }} \mathrm{kg} \mathrm{N} \mathrm{ha}^{-1} \mathrm{yr}^{-1}\right)$ in year $t$ of the different land use systems was calculated using the approach of Palma et al. (2007) and Feldwisch et al. (1998) (Equation 7):

$N_{\text {sur }}=N_{\text {fert }}+N_{\text {adep }}+N_{f i x}+N_{\text {min }}-D-V-U-\mathrm{I}$

Eq. 7

where $N_{\text {fert }}$ was the addition of $\mathrm{N}$ fertiliser, $N_{\text {adep }}$ was the atmospheric deposition, $N_{\text {fix }}$ was the biotic $\mathrm{N}$ fixation, $N_{\min }$ was the mineralisation, $D$ was the denitrification, $V$ was the volatilisation, $U$ was the crop and tree uptake, and I was the immobilisation.

Annual nitrogen fertilisation $\left(N_{\text {fert }}\right)$ for winter wheat, spring barley and oilseed rape was assumed to be 175, 145 and $200 \mathrm{~kg} \mathrm{~N}^{-1}$ respectively (Agro Business Consultants 2015). N atmospheric deposition $\left(N A_{d e p}\right)$ was estimated by summing values of deposition of oxidized and reduced nitrogen from EMEP (2003). Since there was no legume crop, $N$ fixation $\left(N_{f i x}\right)$ was assumed to be $1 \mathrm{~kg} \mathrm{~N} \mathrm{ha}^{-1}$ $\mathrm{yr}^{-1}$ for non-symbiotic organisms (Wild 1993). $\mathrm{N}$ mineralisation $\left(N_{\text {min }}\right)$ and immobilisation $(I)$ were assumed to reach a long-term steady state equilibrium where the quantity of mineral nitrogen released by the soil would be equal to the quantity annually returned to the soil in the form of 
organic matter (Vlek et al. 1981; Noy-Meir and Harpaz 1977). Denitrification (D) was assumed to be $30 \mathrm{~kg} \mathrm{~N} \mathrm{ha}^{-1} \mathrm{yr}^{-1}$ (Palma et al. 2007). Since organic fertilisation was not considered, nitrogen volatilisation $(V)$ was assumed to be derived from mineral $N$ application. Following van Keulen et al. (2000) it was estimated as $5 \%$ of $N_{\text {fert }}$. Nitrogen uptake (U) was estimated as:

$U=\left\{\begin{array}{ccc}\frac{Y_{c}}{\alpha}+\lambda * \beta_{t} & \text { if } & Y_{c}<\frac{Y_{\max }}{2} \\ \frac{4 * Y_{c}-Y_{\max }}{2 * \alpha}+\lambda * \beta_{t} & \text { if } & Y_{c} \geq \frac{Y_{\max }}{2}\end{array}\right.$

where $Y_{c}$ was the harvested crop yield, $Y_{\max }$ was the maximum harvested crop yield $\left(\mathrm{kg} \mathrm{ha}^{-1} \mathrm{yr}^{-1}\right), b_{t}$ was the increment in above-ground tree biomass $\left(\mathrm{kg} \mathrm{ha}^{-1} \mathrm{yr}^{-1}\right)$, $\alpha$ was a unit-less coefficient dependant on the biomass of the crop residue and the harvested product (Equation 9), and $\lambda$ was a unit-less coefficient used to derive tree nitrogen uptake from $b_{t}$ (Equation 10 ). The $\alpha$ coefficient was given as:

$\alpha=\frac{1}{N C_{c}+N C_{r} * \frac{Y_{r}}{Y_{c}}}$

Eq. 9

where $N C_{c}$ and $N C_{r}$ were the $N$ content in the crop grain and straw, respectively (a content of $1 \%$ and $0.4 \% \mathrm{~N}$ in the grain and residue was assumed (van Keulen and Wolf 1986)), and $Y_{r}$ was the residue yield $\left(\mathrm{kg} \mathrm{ha}^{-1} \mathrm{yr}^{-1}\right)$. The $\lambda$ coefficient was given as:

$\lambda=C_{t a b}+C_{t b g} * R S R$

where $C_{\text {tab }}$ and $C_{t b g}$ were the $\mathrm{N}$ content in the aboveground and belowground tree biomass, respectively. A content of $0.66 \%$ and $0.41 \%$ concentration of $\mathrm{N}$ in the tree above ground and below ground biomass respectively was assumed (Gifford 2000a; Gifford 2000b). RSR was the root to shoot ratio of the tree (unit-less). A root to shoot ratio of 0.25 for broadleaved tree species was assumed (IPCC 1996).

\subsubsection{Phosphorus surplus}

An approach similar to $\mathrm{N}$ was used to measure phosphorus surplus $\left(P_{\text {sur }} ; \mathrm{kg} \mathrm{P}_{2} \mathrm{O}_{5} \mathrm{ha}^{-1} \mathrm{yr}^{-1}\right)$. Equation 11 shows the $P$ inputs and outputs considered in the analysis to estimate differences among landuse systems:

$P_{\text {sur }}=\mathrm{P}_{\text {fert }}+\mathrm{PA}_{\text {dep }}-\mathrm{U}$

where $P_{\text {fert }}$ was the addition of $\mathrm{P}_{2} \mathrm{O}_{5}$ fertiliser, $P A_{\text {dep }}$ was the atmospheric deposition and $U$ is the crop and tree uptake (all units in $\mathrm{kg} \mathrm{P}_{2} \mathrm{O}_{5} \mathrm{ha}^{-1} \mathrm{yr}^{-1}$ ).

Phosphorus fertilisation $\left(P_{\text {fert }}\right)$ for winter wheat, spring barley and oilseed rape was assumed to be 60, 55 and $55 \mathrm{~kg} \mathrm{P}_{2} \mathrm{O}_{5} \mathrm{ha}^{-1} \mathrm{yr}^{-1}$, respectively (Agro Business Consultants 2015). Atmospheric deposition $\left(P A_{\text {dep }}\right)$ was assumed to be $0.33 \mathrm{~kg} \mathrm{P} \mathrm{ha}^{-1} \mathrm{yr}^{-1}$ (Tipping et al. 2014). The same equations as in $\mathrm{N}$ were used to calculate $\mathrm{P}_{2} \mathrm{O}_{5}$ uptake. A content of $0.25 \%$ and $0.2 \% \mathrm{P}$ in the grain and residue respectively was assumed (Sandaña and Pinochet 2014). A content of $0.04 \%$ concentration of $P$ in the tree biomass was assumed (Ovington and Madgwick 1958). 


\subsection{Valuation of the environmental externalities}

The environmental externalities were converted into monetary terms using the benefit transfer method which estimates economic values for a study site by transferring available data from previous studies undertaken in another location (Johnston et al. 2015).

The valuation of $\mathrm{CO}_{2} \mathrm{e}$ was based on a value of $€ 7.8\left(\mathrm{t} \mathrm{CO}_{2} \mathrm{e}\right)^{-1}$ currently received by farmers planting woodland in the UK (UK Forestry Commission 2015). Although the Department for Energy and Climate Change (DECC 2009; 2012) predicts that these values will increase over time up to $€ 233$ (t $\left.\mathrm{CO}_{2} \mathrm{e}\right)^{-1}$ at some stage between 2015 and 2045), the current value was used in this study, reflecting a conservative long-term valuation of $\mathrm{CO}_{2} \mathrm{e}$.

Using Graves et al. (2015) the valuation of soil erosion losses was based on the annual off-site cost of dredging of water courses. In this, Jacobs (2008) estimated an annual off-site cost of dredging water courses in England and Wales of $€ 12.9$ million with an agricultural apportionment of $95 \%$, giving a total cost (adjusted to 2009 prices) of $€ 12.2$ million. As Anthony et al. (2009) reported a sediment

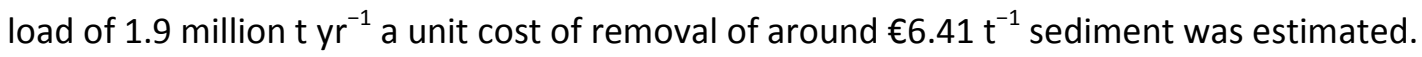

The value for the $\mathrm{N}$ surplus was based on the costs of nitrate removal from freshwater. For the purposes of this study we assumed that, over a long period, the rate of nitrate leaching would be similar to the nitrogen surplus, and that water draining from the site is used for drinking water. Oxera (2006) estimated the upper and lower bound of the cost of nitrate removal to two different water work sizes, expressed as population equivalents (PE). This study selected the more conservative estimate $(P E>100,000)$ which was given as $€ 1.9 \mathrm{~kg} \mathrm{NO}_{3}^{-}(€ 8.4 \mathrm{~kg} \mathrm{~N})$ removed from freshwater. The same cost-based approach used for $\mathrm{N}$ surplus was used to value $\mathrm{P}$ surplus. Again it was assumed that, over a long period, the rate of phosphorus loss would be equivalent to the phosphorus surplus. Using the costs associated with chemical dosing under new phosphate treatment standards (Ofwat 2005), the standard estimate for large works ( $P E>80,000$ ) was equivalent to $€ 5.2 \mathrm{~kg} \mathrm{P}\left(€ 1.14 \mathrm{~kg} \mathrm{P}_{2} \mathrm{O}_{5}\right.$ ) (Ofwat 2005).

\subsection{Economic analysis}

Whilst the financial analysis aimed to show plot-level profitability from a farmer perspective the economic analysis attempted to assess plot-level profitability from a societal perspective. The economic analysis built upon the NPV $V_{F}$ (see Equation 1 ) and included benefits and costs from the five environmental externalities converted into monetary terms $\left(E E_{\mathrm{t}}\right)$ in each year $t$. The NPV for the economic appraisal $\left(N P V_{E}\right)$ was denoted as:

$N P V_{E}=\sum_{t=0}^{n}\left(\left(\frac{\left(R_{t}-V C_{t}-F C_{t}\right)}{(1+i)^{t}}\right)+\left(\frac{E E_{t}}{(1+j)^{t}}\right)\right)$

where $j$ was the assumed discount rate for environmental costs and benefits (here assumed to be $4 \%$ as in the financial analysis). From the NPV $V_{E}$, the economic EAV was calculated as in Equation 2. 


\section{Results}

\subsection{Biophysical simulation}

As described in the method, the average yields in the control arable system were calibrated to match the mean values from the literature for winter wheat, spring barley and oilseed rape in southeastern England (Figure 1a) (Agro Business Consultants 2015). In the silvoarable system, crop yields (expressed per cropped area) were firstly modelled assuming intercropping for all 30 years of the tree rotation (Figure 1b). However from year 15 onwards, the financial analysis showed that the crop component of the silvorable system was no longer profitable due to yield reductions caused by tree competition for water and sunlight. A range of options exist in Farm-SAFE for calculating how long the intercrop rotation should be planted. Here, the year when intercropping was determined to be no longer profitable was calculated by selecting options to identify the first year in which a five-year moving average of the net margin without grants would become zero or less. During the first 14 years, the mean winter wheat, spring barley and oilseed rape were $7.76,6.13$, and $3.16 \mathrm{t} \mathrm{ha}^{-1}$ respectively. These represented mean yield reductions of 15,26 and $6 \%$ respectively compared to the mean yield of the arable plot.

\section{$<$ INSERT FIGURE 1>}

The observed and modelled tree diameter and height, showed that overall tree diameter and height in the forestry system (Figure 2a) was higher than in the silvoarable system (Figure $2 b$ ). The number of trees per hectare was the same for both systems. Over the 30 years, it was estimated that 1.28 ha of separate forestry and arable systems would be needed to produce the crop and timber yields obtained in the silvoarable system. The land equivalent ratio (1.28) was calculated as the sum of the crop production ratio (total crop production in the silvoarable system ( $\mathrm{t} \mathrm{ha}{ }^{-1}$ ) divided by the total crop production in the arable system $\left(\mathrm{t} \mathrm{ha}^{-1}\right)$; Ratio $_{\text {crop }}=0.42$ ) and the timber production ratio (timber production in the silvoarable system $\left(\mathrm{m}^{3} \mathrm{ha}^{-1}\right.$ ) divided by timber production in the forestry system $\left(\mathrm{m}^{3} \mathrm{ha}^{-1}\right)$; Ratio timber $\left.=0.85\right)$.

$<$ INSERT FIGURE 2>

\subsection{Financial analysis}

The biophysical simulation was used to provide the yield data for assessment of the financial profitability of the arable, forestry, and silvorable system, with grants (Figure 3a) and without grants (Figure 3b). Figure 3 shows the discounted financial cumulative net margin of the three land-uses. The cumulative net margin in year 30 indicates the NPV . In both analyses with and without grants, the arable system was the most profitable land-use $\left(\mathrm{NPV}_{\mathrm{F}}\right.$ without grants $\left.=5,444 € \mathrm{ha}^{-1}\right)$ followed by the silvoarable system $\left(\mathrm{NPV}_{\mathrm{F}}\right.$ without grants $\left.=2,069 € \mathrm{ha}^{-1}\right)$ and the forestry system $\left(\mathrm{NPV}_{\mathrm{F}}\right.$ without grants $=1,068 € h a^{-1}$ ). As forestry grants were lower than in the other land uses, the difference in profitability was reduced relative to arable and silvoarable land uses, when excluding grants in the analysis. In the silvoarable system, the cumulative net margin did not substantially increase between years 12 and 29. This was because as the trees developed, the yield and profitability of the 
crop component decreased, and after year 14, cultivating the crop component was no longer profitable.

$<$ INSERT FIGURE 3>

\subsection{Environmental externalities}

The environmental externalities assessed in this study were modelled for all three systems. The overall GHG emissions for the arable system were higher than for both the forestry and silvoarable land uses (Figure 4a). Although the GHG emission from the crop and tree component in the silvoarable system was greater than for the arable system in year 1 , the emissions from the silvoarable system were subsequently lower during crop production (until year 14) and emissions were almost negligible due to the cessation of cropping after year 14.

Carbon sequestered in aboveground timber (Figure 4b) in the forestry system was greater than in the silvoarable system, as the understorey in the forestry system was less competitive for water than the intercrops in the silvoarable system. Because carbon stored in the arable crop was assumed to be rapidly returned to atmosphere after harvest, the aboveground biomass in the arable system was assumed to be zero.

Soil erosion loss by water (Figure 4c) was low in all three land-uses. This was mainly because the area was relatively flat and extreme rainfall events are relatively rare. However, the capacity of tree canopy growth to reduce the annual rate of soil erosion is evident in both the forestry and silvoarable systems.

The $\mathrm{N}$ and $\mathrm{P}_{2} \mathrm{O}_{5}$ surpluses (Figure $4 \mathrm{~d}$ and $4 \mathrm{e}$ respectively) in the arable system were notably greater than in the forestry and silvoarable systems. In the silvoarable system, $\mathrm{N}$ and $\mathrm{P}_{2} \mathrm{O}_{5}$ surplus was greatest in the initial years of the rotation, but as the trees developed, their uptake of $\mathrm{N}$ and $\mathrm{P}_{2} \mathrm{O}_{5}$ increased and $\mathrm{N}$ and $\mathrm{P}_{2} \mathrm{O}_{5}$ surpluses were reduced.

$<$ INSERT FIGURE 4>

\subsection{Economic analysis}

The final stage of our analysis was to assess the profitability of the three land use systems by including the economic value of the environmental externalities. Table 3 shows the annual economic value of the environmental externalities as well as the financial and economic profitability of the systems. The externality with the greatest cost was $\mathrm{N}$ surplus. In the arable system, a mean nitrogen surplus of about $25 \mathrm{~kg} \mathrm{~N} \mathrm{ha}^{-1}$ was associated with an environmental cost of $186 € \mathrm{ha}^{-1} \mathrm{yr}^{-1}$. Soil erosion loss by water was the externality with the lowest economic impact; its greatest value was in the arable system where a mean annual loss of $0.4 \mathrm{t}_{\text {soil }} \mathrm{ha}^{-1}$ was estimated to cause an economic impact costing $2.5 € \mathrm{ha}^{-1} \mathrm{yr}^{-1}$. Although trees are sometimes planted in Eastern England to reduce wind erosion this was not included here because the calculation of wind erosion requires a spatially dependent analysis of wind direction and tree distribution. However, it is worth highlighting that inclusion of the effect of trees on reducing wind erosion would have increased the economic value of the forestry and agroforestry systems. 
The results show that both with and without grants, the arable system was the most financially profitable land-use $\left(E_{A V}\right.$ with grants $\left.=559 € \mathrm{ha}^{-1} \mathrm{yr}^{-1}\right)$ followed by the silvoarable $\left(\mathrm{EAV}_{\mathrm{F}}\right.$ with grants $=$ $\left.364 € \mathrm{ha}^{-1} \mathrm{yr}^{-1}\right)$ and the forestry system $\left(\mathrm{EAV}_{\mathrm{F}}\right.$ with grants $\left.=194 € \mathrm{ha}^{-1} \mathrm{yr}^{-1}\right)$. However, these results were altered when the environmental externalities were included. In this case, the economic performance of the silvoarable system $\left(E A V_{E}\right.$ with grants $\left.=353 € \mathrm{ha}^{-1} \mathrm{yr}^{-1}\right)$ was similar to that of arable system $\left(E A V_{E}\right.$ with grants $\left.=343 € h^{-1} \mathrm{yr}^{-1}\right)$ and greater than that of the forestry $\left(E^{-1 V_{E}}\right.$ with grants $\left.=228 € \mathrm{ha}^{-1} \mathrm{yr}^{-1}\right)$.

$<$ INSERT TABLE 3>

\section{Discussion}

Analyses of agroforestry economics in Europe tends to focus on their financial performance relative to arable and forestry counterfactuals (Graves et al. 2007) whilst at the same time noting that the lack of externalities in economic assessments is a gap in research that needs to be filled. This analysis advances knowledge of the overall contribution of land use systems to society by taking both a financial and economic perspective of the relative value of arable, forestry, and silvoarable systems.

The estimated mean $\mathrm{CO}_{2} \mathrm{e}$ emission in the arable system was $2.4 \mathrm{t} \mathrm{CO}_{2} \mathrm{e} \mathrm{ha} \mathrm{Cr}^{-1}$. Camargo et al. (2013) estimated values for wheat, barley and oilseed rape of 1.5-2.0 t $\mathrm{CO}_{2} \mathrm{e} \mathrm{ha}^{-1} \mathrm{yr}^{-1}$. Williams et al. (2010) estimated a global warming potential for wheat of around $0.7 \mathrm{t} \mathrm{CO}_{2} \mathrm{e}$ produced $\mathrm{t}^{-1}$, which assuming a yield of $9 \mathrm{t} \mathrm{ha}^{-1}$ would be equivalent to $6.3 \mathrm{CO}_{2} \mathrm{e} \mathrm{ha} \mathrm{Hr}^{-1}$. This higher value included the contribution of $\mathrm{N}_{2} \mathrm{O}$ emissions and operations beyond the field-gate such as crop storage and drying. Compared to the arable system, $\mathrm{CO}_{2} \mathrm{e}$ emissions per hectare in the silvoarable system were reduced by $56 \%$, but $\mathrm{CO}_{2}$ e emissions per tonne of crop increased by $4.4 \%$ in the silvoarable system.

Mean carbon sequestration in the silvorable system (determined only as carbon stored as timber) was $4 \mathrm{t} \mathrm{CO}_{2} \mathrm{e} \mathrm{ha}{ }^{-1} \mathrm{yr}^{-1}$. Palma et al. (2007) estimated values between 1.83 and $8.8 \mathrm{t} \mathrm{CO}_{2} \mathrm{e} \mathrm{ha}^{-1} \mathrm{yr}^{-1}$ for poplar trees in a silvoarable system in the Netherlands. Compared to the forestry system, aboveground carbon sequestration in the silvoarable system was reduced by $15 \%$. The study did not consider the effect of the silvoarable agroforestry system on below-ground carbon storage. Measurements at the same site (Upson and Burgess, 2013), indicate that whilst agroforestry increased soil carbon at a depth of $20-40 \mathrm{~cm}$ by $0.77 \mathrm{t} \mathrm{C} \mathrm{ha}^{-1} \mathrm{yr}^{-1}$, relative to the arable system, the effect was not significant when greater depths were considered.

The results showed that $\mathrm{CO}_{2} \mathrm{e}$ emissions per hectare in the silvoarable system were lower than in the arable system but the opposite occurred when the considered units were $\mathrm{CO}_{2} \mathrm{e}$ emissions per tonne of crop. However, when carbon sequestration and emissions were considered together the results notably varied. In the arable system, as aboveground carbon sequestration was assumed to be zero the carbon balance did not change. However, in the silvoarable system the balance became negative, i.e. more carbon was sequestered than emitted. Thus, when carbon sequestration and emissions were considered together, net emissions per hectare and per tonne of crop were notably lower in the silvoarable system than in the arable system. 
Soil erosion loss by water in the three land uses was lower than $0.4 \mathrm{t} \mathrm{ha}^{-1} \mathrm{yr}^{-1}$, a value that is relatively low compared to other areas in Europe (Panagos et al. 2015d). This can be explained by the relatively-flat case study area and the lack of extreme rainfall events. Hence the economic cost of soil erosion at $1.5-2.5 €$ ha $^{-1} \mathrm{yr}^{-1}$ was also low. Compared to the arable system, soil erosion loss in the silvoarable system was reduced by about $50 \%$. Whilst the absolute effect was low in this casestudy, on more steep slopes and in areas with more extreme rainfall, the benefits could be substantial.

Annual loss of $\mathrm{N}$ was the costliest environmental externality. In the arable system, the mean $\mathrm{N}$ loss was about $25 \mathrm{~kg} \mathrm{~N} \mathrm{ha}^{-1} \mathrm{yr}^{-1}$ which is within the range of estimated annual $\mathrm{N}$ losses from temperate European arable systems of 10-100 kg N ha ${ }^{-1} \mathrm{yr}^{-1}$ (Nemeth 1996; Hoffmann and Johnsson 2003). In the silvoarable system, the modelled mean annual $\mathrm{N}$ loss during the years when the intercrop was cultivated (0-14 years) was $4.7 \mathrm{~kg} \mathrm{~N} \mathrm{ha}^{-1}$, which is equivalent to an $80 \%$ reduction compared to the arable control. This was a result of a lower fertiliser rate per hectare because $20 \%$ of the area was not cropped $(-20 \%)$ and nitrogen uptake by the trees and grass in the tree rows. This is greater than the $37 \%$ reduction reported by Udawatta et al. (2002) in young temperate agroforestry systems. However, Udawatta et al only reported the reduction for the first three years, greater reductions could be anticipated as the trees grow. In fact, when only the first three years of the rotation were considered, the reduction of $\mathrm{N}$ loss was $36 \%$ in the silvorable system, similar to that observed by Udawatta et al. (2002). Similar reduction effects were seen in the case of $\mathrm{P}_{2} \mathrm{O}_{5}$ loss. Whilst in the arable system, the loss was $8.0 \mathrm{~kg} \mathrm{P}_{2} \mathrm{O}_{5} \mathrm{ha}^{-1} \mathrm{yr}^{-1}$, in the silvoarable system it was $0.4 \mathrm{~kg} \mathrm{P}_{2} \mathrm{O}_{5} \mathrm{ha}^{-1} \mathrm{yr}^{-1}$ for the whole rotation turn and $0.9 \mathrm{~kg} \mathrm{P}_{2} \mathrm{O}_{5} \mathrm{ha}^{-1} \mathrm{yr}^{-1}$ during the years when the crop was cultivated.

There are a number of recommendations for future research that flow from this paper. As with all case study research it is important to consider that specific conditions change with location, and new analyses are likely to be required to assess the performance of competing land use systems at other sites (García de Jalón et al. 2014). Many environmental processes operate at a landscape scale, where surrounding topography and land uses become important, for example, having a bearing on rates of soil erosion, $\mathrm{N}$ and $\mathrm{P}$ losses into water bodies, if the plots are located far, rather than near to them. Further research could build on the results of this study through a bottom-up approach to upscale the provision and economic value of the environmental externalities at the landscape level. Detailed spatial data would be necessary to adequately conduct this upscaling. It should be noted however, that whilst modelling environmental externalities at a landscape scale is desirable for some environmental processes, it can also lead to a reduction in specific detail (Tscharntke et al. 2005; Palma et al. 2007). Whilst we have made good progress in quantifying and valuing a number of environmental externalities, others such as habitat for wildlife, landscape diversity, pollination services, air quality, noise reduction, need yet to be assessed. Past research has indicated that trees have the potential to improve such ecosystem services (Sing et al. 2015; Faber et al. 2002) and if these environmental externalities are included in future analyses, the economic profitability of forestry and silvoarable system may increase further relative to arable systems.

\section{Conclusion}

Based on an experimental plot in Bedfordshire in the UK, this paper modelled the financial profitability and valued the environmental externalities for an arable, silvoarable and forestry 
system. The results showed that the arable system was the most financially profitable land use but produced the most negative externalities. The silvoarable system whilst more profitable than the forestry system also produced greater negative externalities. The inclusion of the economic value of GHG emissions, carbon sequestration and loss of soil, $\mathrm{N}$ and $\mathrm{P}$ showed that silvoarable agroforestry provided a similar economic performance as the arable system, and a greater benefit than the forestry system. The expense of removing $\mathrm{N}$ and $\mathrm{P}$ in freshwater meant that these costs were particularly high in the arable system. Compared to arable systems, the results showed that silvoarable systems are particularly advantageous in environmental aspects. Thus giving the right price to negative externalities via policy and funding could help make the best environmental system competitive in economic terms. Overall, the results showed that planting trees in arable systems could potentially reduce nutrient surpluses and provide a large economic benefit to society. Inclusion of other environmental externalities that were not considered in this analysis but are associated to land-use activities could increase the relative value of incorporating trees in agricultural systems.

\section{Acknowledgements}

We acknowledge support of the European Commission through the AGFORWARD FP7 research project (contract no. 613520). The silvoarable experiment received funding from the UK Ministry of Agriculture, Fisheries and Food (1992-1997) and the UK Department of Environment, Food and Rural Affairs (1999-2003). The analysis of tree measurements in 2011 were made with the support of the Forestry Commission and the Scottish Forestry Trust.

\section{References}

Agro Business Consultants (2015) The Agricultural Budgeting \& Costing Book. $82^{\text {th }}$ Edition. Melton Mowbray: Agro Business Consultants. Leicestershire, UK

Anthony S, Duethman D, Gooday R, Harris D, Newell-Price P, Chadwick D, Misselbrook T, (2009) Quantitative Assessment of Scenarios for Managing Trade-Off between the Economic Performance of Agriculture and the Environment and Between Different Environmental Media. Final Report, Defra Project WQ0106 (Module 6), 95 pp

Burgess PJ, Crous-Duran J, den Herder M, Dupraz C, Fagerholm N, Freese D, Garnett K, Graves AR, Hermansen JE, Liagre F, Mirck J, Moreno G, Mosquera-Losada MR, Palma JHN, Pantera A, Plieninger T, Upson M (2015) AGFORWARD Project Periodic Report: January to December 2014. Cranfield University: AGFORWARD. $45 \mathrm{pp}$. https://www.agforward.eu/index.php/en/news-reader/id-27-february-2015.html

Burgess PJ, Incoll LD, Corry DT, Beaton A, Hart BJ (2005) Poplar (Populus spp) growth and crop yields in a silvoarable experiment at three lowland sites in England. Agroforestry Systems 63 (2):157-169

Burgess PJ, Morris J (2009) Agricultural technology and land use futures. Land Use Policy 26S: S222S229 
Camargo GGT, Ryan MR, Richard TL (2013) Energy Use and Greenhouse Gas Emissions from Crop Production Using the Farm Energy Analysis Tool. BioScience 63:263-273

DECC (2009) Carbon Valuation in UK Policy Appraisal: A Revised Approach, pp 1-128

DECC (2012) Updated short-term traded carbon values used for UK public policy appraisal, pp 1-8

Dupraz C, Burgess P, Gavaland A, Graves A, Herzog F, Incoll LD, Jackson N, Keesman K, Lawson G, Lecomte I, Liagre F, Mantzanas K, Mayus M, Moreno G, Palma J, Papanastasis V, Paris P, Pilbeam DJ, Reisner Y, van Noordwijk M, Vincent G, van der Werf W (2005) SAFE final reportSynthesis of the Silvoarable Agroforestry For Europe project. INRA-UMR System Editions, European Union

Dupraz C, Vincent G, Lecomte I, Bussière F, Sinoquet H (2004) Above-ground modules in Hi-SAFE (Tree phenology, tree $\mathrm{C}$ allocation, tree light interception, microclimate). Deliverable D.4.1 in Silvoarable Agroforestry For Europe (SAFE). European Research contract QLK5-CT-200100560)

EMEP (2003) Cooperative Programme for Monitoring and Evaluation of the Long-range Transmission of Air Pollutants in Europe. Available at: www.emep.int. Accessed in January 2017

EU (2013) Regulation (EU) No 1306/2013 of the European Parliament and of the Council of 17 December 2013 on the financing, management and monitoring of the common agricultural policy and repealing Council Regulations (EEC) No 352/78, (EC) No 165/94, (EC) No 2799/98, (EC) No 814/2000, (EC) No 1290/2005 and (EC) No 485/2008 (OJ L 347 of 20.12.2013, p 1)

Farber SC, Costanza R, Wilson MA (2002) Economic and ecological concepts for valuing ecosystem services. Ecological Economics 41:375-392

Feldwisch N, Frede H, Hecker F, (1998) Verfahren zum Abschätzen der Erosions und Auswaschungsgefahr. In: Frede, H, Dabbert, S. (Eds.), Handbuch zum Gewässerschutz in der Landwirtschaft. Ecomed, Landsberg, pp 22-57

García de Jalón S, Iglesias A, Cunningham R, Pérez Díaz JI (2014). Building resilience to water scarcity in Southern Spain: A case study of rice farming in Doñana protected wetlands. Regional Environmental Change 14 (3): 1229-1242.

Gifford R (2000a) Carbon Content of Woody Roots: Revised Analysis and a Comparison with Woody Shoot Components. National Carbon Accounting System Technical Report No. 7 (Revision 1), Australian Greenhouse Office, Canberra, $10 \mathrm{pp}$

Gifford R (2000b) Carbon Contents of Above-Ground Tissues of Forest and Woodland Trees, National Carbon Accounting System. Technical Report No. 22, Australian Greenhouse Office, Canberra, $24 \mathrm{pp}$

Graves AR, Burgess PJ, Liagre F, Terreaux J-P, Borrel T, Dupraz C, Palma J, Herzog F (2011) Farm-SAFE: the process of developing a plot- and farmscale model of arable, forestry, and silvoarable economics. Agroforestry Systems 81:93-108 
Graves AR, Burgess, PJ Palma JHN, Herzog F, Moreno G, Bertomeu M, Dupraz C, Liagre F, Keesman K, van der Werf W, Koeffeman de Nooy A, van den Briel JP (2007) Development and application of bio-economic modelling to compare silvoarable, arable and forestry systems in three European countries. Ecological Engineering 29:434-449

Graves AR, Morris J, Deeks L, Rickson J, Kibblewhite M, Harris J, Fairwell T, Truckle I (2015) The cost of soil degradation in England and Wales. Ecological Economics 119:399-413

HM Treasury (2003). The Green Book: Appraisal and Evaluation in Central Government. London: TSO.

https://www.gov.uk/government/uploads/system/uploads/attachment data/file/220541/gr een book complete.pdf

Hoffman M, Johnson H (2003) Test of a modelling system for estimating nitrogen leaching - a pilot study in a small agricultural catchment. Environ Model Assess 8 (1):15-23

IPCC (1996) Revised 1996 IPCC Guidelines for National Greenhouse Gas Inventories: Reference Manual

JACOBS (2008) Environmental accounts for agriculture. Defra Project SFS0601Final report. JACOBS UK Ltd

John Nix Farm Management Pocketbook (2014) John Nix Farm Management Pocketbook. 44 ${ }^{\text {th }}$ Edition. Melton Mowbray: Agro Business Consultants. Leicestershire, UK

Johnston RJ, Rolfe J, Rosenberger RS, Brouwer R (2015) Introduction to Benefit Transfer Methods. In: Johnston, R.J, Rolfe, J, Randall, S, Rosenberger, R.S. Brouwer, R. Benefit Transfer of Environmental and Resource Values. A Guide for Researchers and Practitioners. Springer Science+Business Media Dordrecht, pp 1-582

Liagre F (1997) ARBUSTRA Manuel de l'utilisateur. User manual for ARBUSTRA, Centre Régional de la Propriété Forestiere (CRPF) and I'Institut National de la recherché Agronomique (INRA)Montpellier, France, pp 1-71

Nair PKR (2011) Methodological Challenges in Estimating Carbon Sequestration Potential of Agroforestry Systems. In Kumar, B. M. and Nair, P. K. R. (eds.) Carbon Sequestration Potential of Agroforestry Systems: Opportunities and Challenges. Heidelberg: Springer, pp 316

Nemeth T (1996) Nitrogen balances in long term field experiments. Fertiliser Res 43 (1-3):13-19

Noy-Meir I, Harpaz Y (1977) Agro-ecosystems in Israel. In: Harper, J, Gruys, P. (Eds.), AgroEcosystems, vol. 4. Elsevier Scientific Publishing, Amsterdam, pp 143-167

OFWAT (2005) Water Framework Directive - Economic Analysis of Water Industry Costs. Final Report. Water Services Regulation Authority. Oxford 
Ovington JD, Madgwick HAI (1958) The sodium, potassium and phosphorus contents of tree species grown in close stands. New Phytologist. Version of Record online 2 MAY 2006 57(3). DOI: 10.1111/j.1469-8137.1958.tb05316.x

OXERA (2006) What is the cost of reducing ammonia, nitrates and BOD in sewage treatment works effluent? Prepared for Ofwat. Oxford. Available at: http://www.ofwat.gov.uk/wpcontent/uploads/2015/11/rpt com oxera080107.pdf

Palma JHN (2015). CliPick: Project Database of Pan-European Climate Data for Default Model Use. Milestone Report 26 (6.1) for EU FP7 Research Project: AGFORWARD 613520. 10 October 2015. 22 pp. http://www.agforward.eu/index.php/en/clipick-project-database-of-paneuropean-simulated-climate-data-for-default-model-use.html

Palma JHN, Graves AR, Burgess PJ, Keesman KJ, van Keulen H, Mayus M, Reisner Y, Herzog F (2007) Methodological approach for the assessment of environmental effects of agroforestry at the landscape scale. Ecological Engineering 29 (4):450-462

Panagos P, Ballabio C, Borrelli P, Meusburger K, Klik A, Rousseva S, Tadic MP, Michaelides S, Hrabalíková M, Olsen P, Aalto J, Lakatos M, Rymszewicz A, Dumitrescu A, Beguería S, Alewell C (2015a) Rainfall erosivity in Europe. Science of Total Environment 511:801-814

Panagos P, Borrelli P, Meusburger K (2015b) A New European Slope Length and Steepness Factor (LSFactor) for Modeling Soil Erosion by Water. Geosciences 5:117-126

Panagos P, Borrelli P, Meusburger K, van der Zanden EH, Poesen J, Alewell C (2015c) Modelling the effect of support practices (P-factor) on the reduction of soil erosion by water at European Scale. Environmental Science \& Policy 51:23-34

Panagos P, Borrelli P, Poesen J, Ballabio C, Lugato E, Meusburger K, Montanarella L, Alewell C (2015d) The new assessment of soil loss by water erosion in Europe. Environmental Science \& Policy 54:438-447

Panagos P, Meusburger K, Ballabio C, Borrelli P, Alewell C (2014) Soil erodibility in Europe: A highresolution dataset based on LUCAS. Science of Total Environment 479-480:189-200

Sandaña P, Pinochet D (2014) Grain yield and phosphorus use efficiency of wheat and pea in a high yielding environment. Journal of Soil Science and Plant Nutrition 14 (4):973-986

Sing L, Ray D, Watts K (2015) Ecosystem services and forest management. Research Note. UK Forestry Commission. Available at: http://www.forestry.gov.uk/pdf/FCRN020.pdf/\$FILE/FCRN020.pdf

Thomas TH (1991) A spreadsheet approach to the economic modelling of agroforestry systems. Forest Ecology and Management 45:207-235

Tipping E, Benham S, Boyle JF, Crow P, Davies J, Fischer U, Guyatt H, Helliwell R, Jackson-Blake L, Lawlor AJ, Monteith DT, Roweg EC, Toberman H (2014) Atmospheric deposition of phosphorus to land and freshwater. Environmental Science: Processes and Impacts 16:16081617 
Tscharntke T, Klein AM, Kruess A, IfSteffan-Dewenter I, Thies C (2005) Landscape perspectives on agricultural intensification and biodiversity - Ecosystem service management. Ecology Letters 8(8):857-874

Udawatta RP, Krstansky JJ, Henderson GS, Harold E (2002) Agroforestry Practices, Runoff, and Nutrient Loss: A Paired Watershed Comparison. J Environ Qual 31(4):1214-1225

UK Forestry Commission (2015) UK Woodland Carbon Code. Available at: www.forestry.gov.uk/carboncode

Upson M, Burgess PJ (2013) Soil organic carbon and root distribution in a temperate arable agroforestry system. Plant and Soil 373:43-58

Van der Werf W, Keesman K, Burgess P, Graves A, Pilbeam D, Incoll LD, Metselaar K, Mayus M, Stappers R, van Keulen H, Palma J, Dupraz C (2007) 'Yield-SAFE: A parameter-sparse, process-based dynamic model for predicting resource capture, growth, and production in agroforestry systems'. Ecological Engineering 29(4):419-433

van Keulen H, Aarts H, Habekotte B, van der Meer H, Spiertz J (2000) Soil-plant-animal relations in nutrient cycling: the case of dairy farming system 'De Marke'. Eur J Agron 13 (2/3):245-261

van Keulen H, Wilf J (1986) Crop production as determined by nutrient availability. In: Modelling of agricultural production: Weather, Soils and Crops. Simulation Monographs, Pudoc, Wageningen, pp 153-181

van Noordwijk M, Lusiana B (1999) WaNuLCAS, a Model of Water, Nutrient and Light Capture in Agroforestry Systems. Agroforestry Systems 43(1-3): 217-242

Vlek P, Fillery I, Burford J (1981) Accession, transformation, and loss of nitrogen in soils of the arid region. Plant Soil 58:133-175

Wild A (1993) Soils and the Environment: An Introduction. Cambridge University Press, Cambridge

Williams AG, Audsley E, Sandars DL (2010) Environmental burdens of producing bread wheat, oilseed rape and potatoes in England and Wales using simulation and system modelling. International Journal of Life Cycle Assessment 15(8):855-868

Young A, Menz K, Muraya P, Smith C (1998) SCUAF Version 4: a model to estimate soil changes under agriculture, agroforestry and forestry. ACIAR Technical Report Series no. 41, ACIAR, Canberra, Australia, pp 1-49 
Table 1. Assumptions for crop revenues and costs in the analysis

\begin{tabular}{|c|c|c|c|c|c|c|c|c|}
\hline \multirow[t]{2}{*}{ Crop } & \multirow{2}{*}{$\begin{array}{l}\text { Grain } \\
\text { price } \\
\left(€ \mathrm{t}^{-1}\right)\end{array}$} & \multirow{2}{*}{$\begin{array}{l}\text { Seed } \\
\text { rate } \\
\left(\mathrm{kg} \mathrm{ha}^{-1}\right)\end{array}$} & \multicolumn{3}{|c|}{ Fertiliser rate } & \multirow{2}{*}{$\begin{array}{l}\text { Variable } \\
\text { costs }^{1} \\
\left(€ \text { ha }^{-1}\right)\end{array}$} & \multirow{2}{*}{$\begin{array}{l}\text { Fixed costs } \\
(\text { exc. labour })^{2} \\
\left(€ \mathrm{ha}^{-1}\right)\end{array}$} & \multirow{2}{*}{$\begin{array}{l}\text { Labour } \\
\text { costs } \\
\left(€ \mathrm{ha}^{-1}\right)\end{array}$} \\
\hline & & & $\left(\mathrm{kg} \mathrm{N} \mathrm{ha}^{-1}\right)$ & $\left(\mathrm{kg} \mathrm{P}_{2} \mathrm{O}_{5} \mathrm{ha}^{-1}\right)$ & $\left(\mathrm{kg} \mathrm{K}_{2} \mathrm{O} \mathrm{ha}^{-1}\right)$ & & & \\
\hline Wheat & 174 & 160 & 175 & 60 & 55 & 653 & 444 & 162 \\
\hline Barley & 160 & 155 & 145 & 55 & 40 & 653 & 444 & 146 \\
\hline Oilseed & 361 & 5 & 200 & 55 & 45 & 535 & 444 & 151 \\
\hline
\end{tabular}

(1) Includes seed, fertiliser, spray and other costs.

(2) Includes costs relating to fuel and repairs, machinery, interest on working capital, installation, rent and other fixed costs. 
Table 2. Summary of costs associated with the tree component of the systems.

\begin{tabular}{|c|c|c|c|}
\hline Tree operations & Units & Forestry & Silvoarable \\
\hline Establishment cost (total) & $\left(€ h^{-1}\right)$ & 753.28 & 753.28 \\
\hline Costs of individual plants & $\left(€\right.$ tree $\left.^{-1}\right)$ & 1.33 & 1.33 \\
\hline Costs of individual tree protection & $\left(€\right.$ tree $\left.^{-1}\right)$ & 0.27 & 0.27 \\
\hline Costs of tree mulch & $\left(€\right.$ tree $\left.^{-1}\right)$ & 0.40 & 0.40 \\
\hline Costs of ground preparation & $\left(€ \mathrm{ha}^{-1}\right)$ & 48.93 & 48.93 \\
\hline Labour for planting trees & $\left(\min\right.$ tree $\left.^{-1}\right)$ & 3.00 & 3.00 \\
\hline Labour for tree protection & $\left(\min\right.$ tree $\left.^{-1}\right)$ & 0.40 & 0.40 \\
\hline Labour for tree mulch & $\left(\min\right.$ tree $\left.^{-1}\right)$ & 1.70 & 1.70 \\
\hline Weeding cost (total) & $\left(€ \mathrm{ha}^{-1}\right)$ & 10.40 & 22.93 \\
\hline Single herbicide for tree row & $\left(\min \mathrm{m}^{-2}\right)$ & 0.08 & 0.00 \\
\hline Annual cost of herbicide & $\left(€ \text { tree }^{-1}\right)^{\prime}$ & 0.00 & 0.002 \\
\hline Removal of mulch & $\left(\min\right.$ tree $\left.^{-1}\right)$ & 1.50 & 0.00 \\
\hline Grass cut between tree rows & $\left(€\right.$ ha $\left.^{-1}\right)$ & 0.00 & 20.00 \\
\hline Labour to establish grass sward & $\left(\min \mathrm{m}^{-2}\right)$ & 0.50 & 0.00 \\
\hline Labour to maintain grass sward & $\left(\min \mathrm{m}^{-2}\right)$ & 0.30 & 0.00 \\
\hline Labour to tree maintenance & $\left(\min\right.$ tree $\left.^{-1}\right)$ & 1.20 & 1.20 \\
\hline Pruning cost (total) & $\left(€ h^{-1}\right)$ & 805.06 & 805.06 \\
\hline Height first prune & $(\mathrm{m})$ & 1.00 & 1.00 \\
\hline Labour first prune & $\left(\min\right.$ tree $\left.^{-1}\right)$ & 1.00 & 1.00 \\
\hline Height last prune & $(\mathrm{m})$ & 8.00 & 8.00 \\
\hline Labour last prune & $\left(\min\right.$ tree $\left.^{-1}\right)$ & 15.00 & 15.00 \\
\hline Removal of prunings & $\left(\min\right.$ tree $\left.^{-1}\right)$ & 4.00 & 4.00 \\
\hline Harvest cost (total) & $\left(€\right.$ ha $\left.^{-1}\right)$ & 583.96 & 583.96 \\
\hline Tree cutting & $\left(\min\right.$ tree $\left.^{-1}\right)$ & 7.00 & 7.00 \\
\hline Admin. and insurance and other cost (total) & $\left(€ \mathrm{ha}^{-1}\right)$ & 90.00 & 90.00 \\
\hline Administrative, insurance and tax cost & $\left(€ \mathrm{ha}^{-1}\right)$ & 9.00 & 9.00 \\
\hline Average annual maintenance costs & $\left(€\right.$ ha $^{-1}$ year $\left.^{-1}\right)$ & 51.28 & 51.40 \\
\hline
\end{tabular}


Table 3. Financial and Economic Equivalent Annual Value (EAV) of an arable, forestry and silvoarable system in Bedfordshire in the United Kingdom. Results shown for a time horizon of 30 years at a $4 \%$ discount rate.

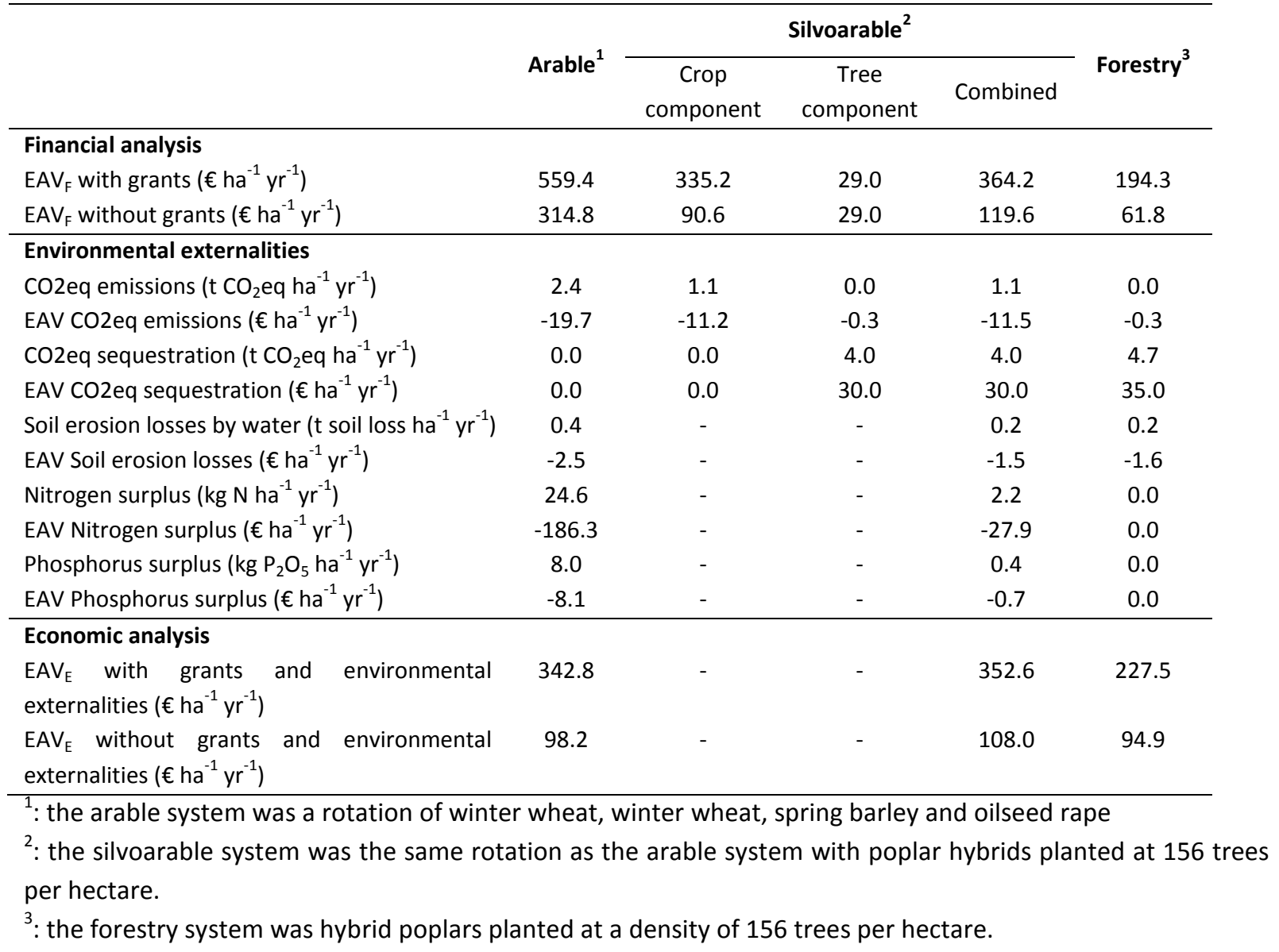


a) Arable system

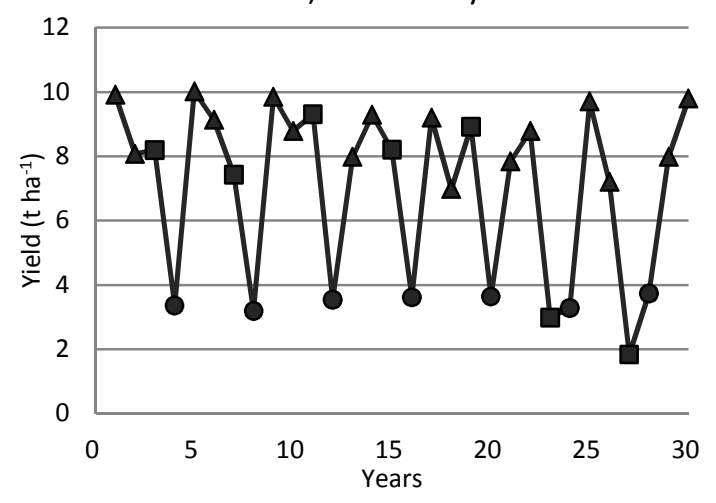

b) Silvoarable system

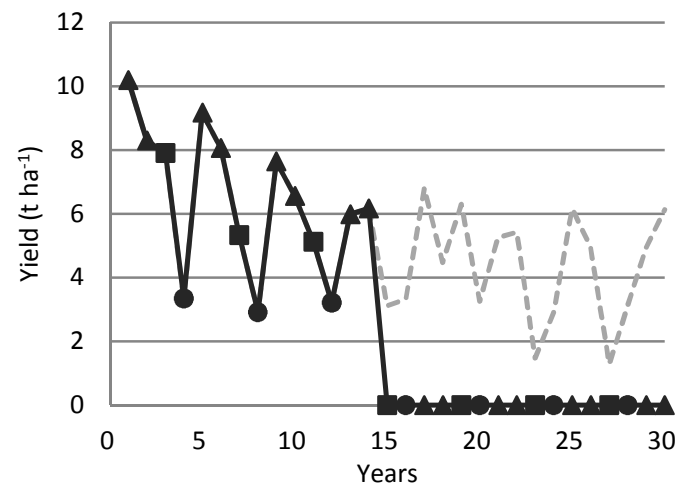

$\longrightarrow$ Winter wheat yield

$\longrightarrow$ Spring barley yield

$\longrightarrow$ Oilseed rape yield

..... Crops yield (no override)

Figure 1. Modelled crop yields (per cropped area). Figure 1.a shows the control arable and Figure 1.b the silvoarable system. 
a) Tree height

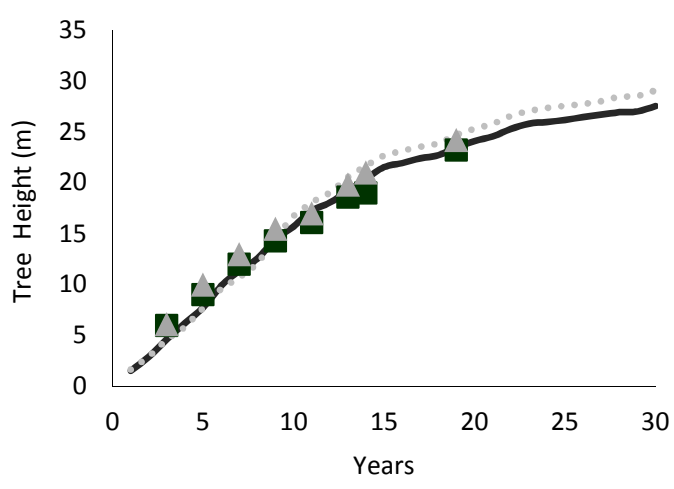

b) Tree diameter

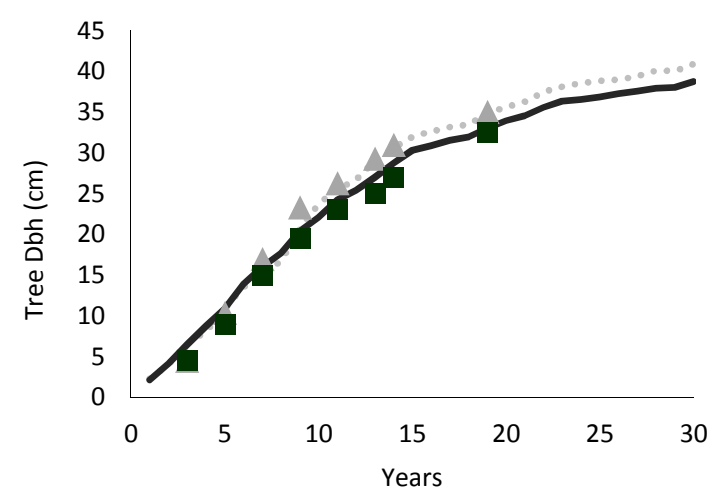

.... Modelled forestry data

$\Delta \quad$ Observed forestry data

Modelled silvoarable data

- Observed silvoarable data

Figure 2. Observed and modelled height (Figure 2.a) and diameter at breast height ( $\left.D_{\text {bh }}\right)$ (Figure 2.b) of the poplar trees in the forestry and silvoarable system. 
a) With grants

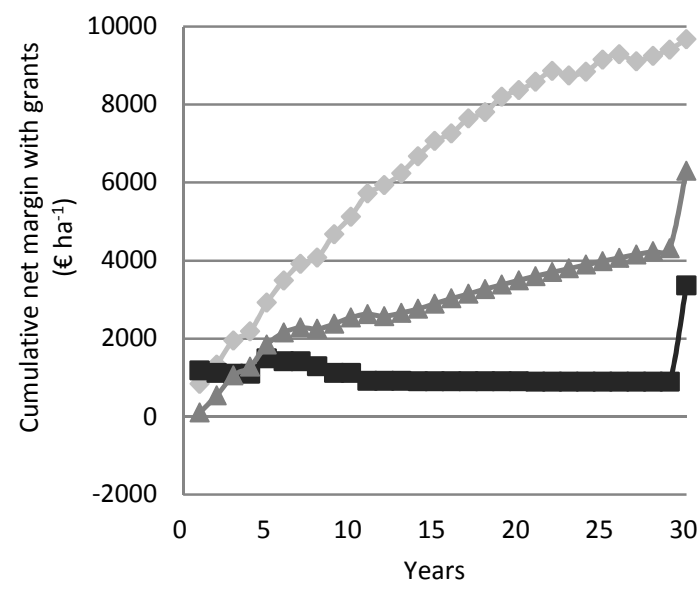

b) Without grants

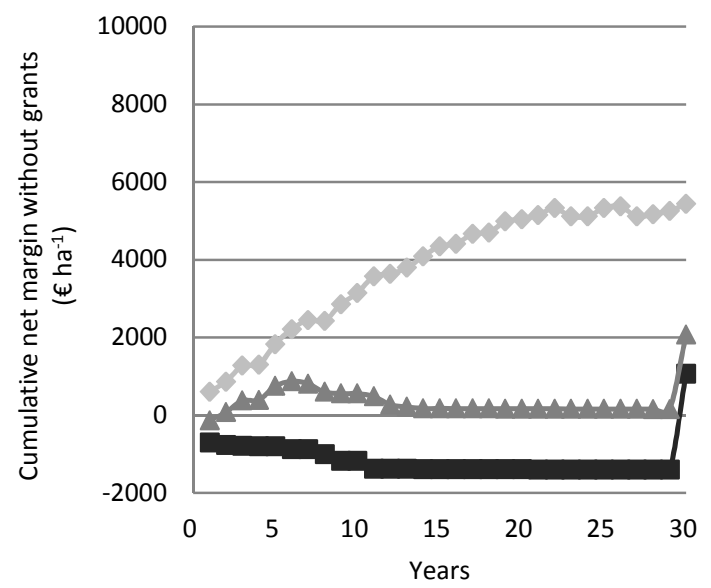

$\rightarrow$ Arable system: a rotation of winter wheat, winter wheat, spring barley and oilseed rape

Silvoarable system: same rotation as the arable system with poplar hybrids planted at 156 trees per hectare

- Forestry system: hybrid poplars planted at a density of 156 trees per hectare

Figure 3. Financial cumulative net margin (assuming a discount rate of $4 \%$ ) in the arable, forestry and silvoarable system. Figure 3.a shows the financial cumulative net margin with grants. Figure 3.b shows the financial cumulative net margin without grants. 
a) GHG emissions

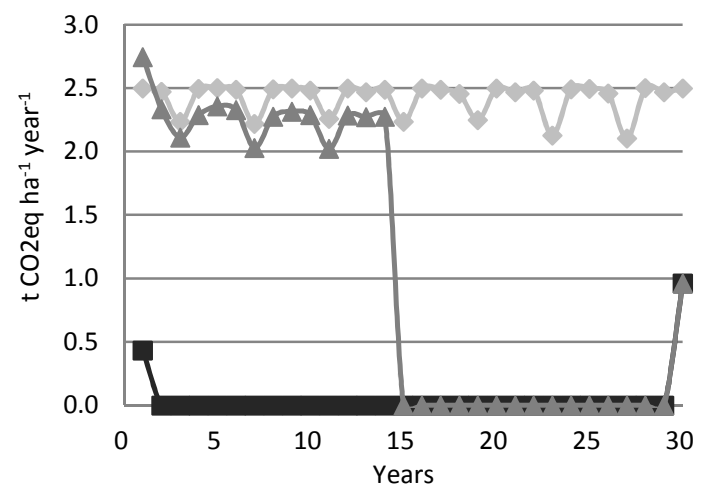

c) Soil erosion losses by water
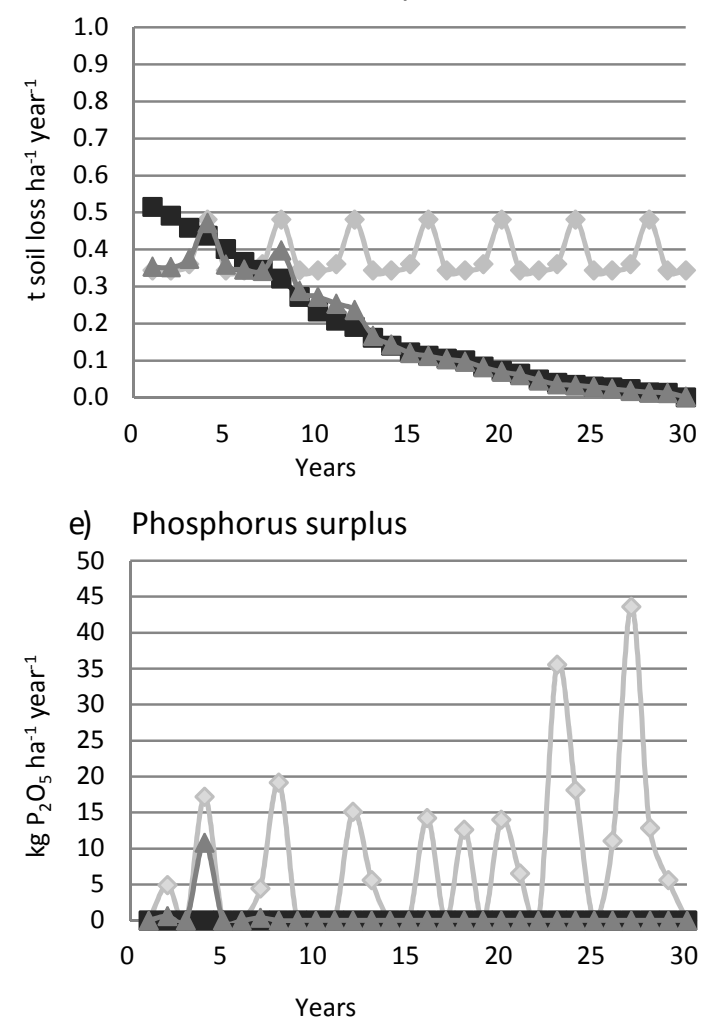

b) Carbon sequestration in aboveground biomass

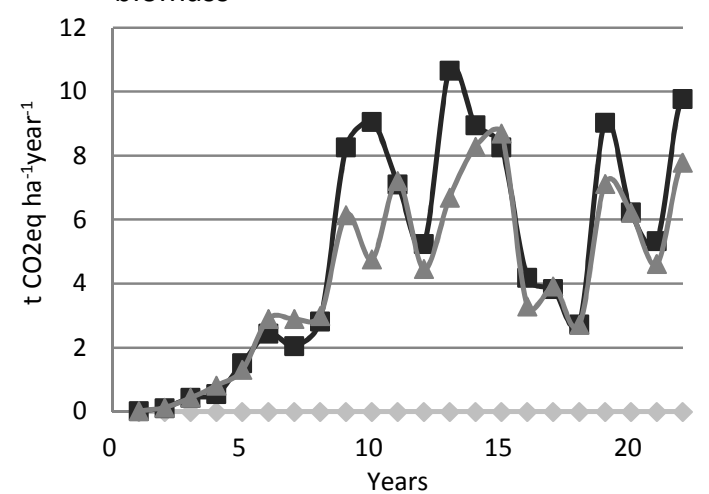

d) Nitrogen surplus

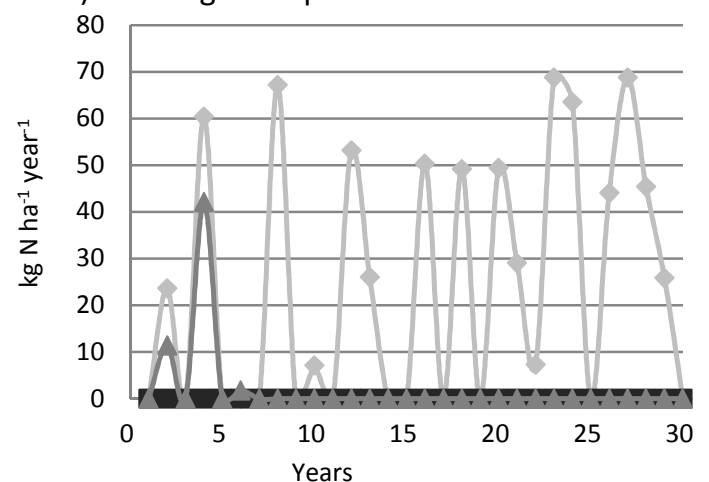

$\sim$ Arable system: a rotation of winter wheat, winter wheat, spring barley and oilseed rape

- Silvoarable system: same rotation as the arable system with poplar hybrids planted at 156 trees per hectare

- Forestry system: hybrid poplars planted at a density of 156 trees per hectare

Figure 4. Modelled environmental externalities of the arable, forestry, and silvoarable system over a time horizon of 30 years in terms of a) GHG emissions, b) aboveground carbon sequestration, c) soil erosion, d) nitrogen surplus, and e) phosphorus surplus. 